\title{
Effect of transport on pulsatile and surge secretion of LH in ewes in the breeding season
}

\author{
H. Dobson, J. E. Tebble, J. B. Phogat and R. F. Smith \\ Department of Veterinary Clinical Science and Animal Husbandry, University of Liverpool, Leahurst, Neston, South Wirral L64 7TE, UK
}

\begin{abstract}
The aim of this study was to elucidate the mechanism(s) involved in stress-induced subfertility by examining the effect of $4 \mathrm{~h}$ transport on surge and pulsatile $\mathrm{LH}$ secretion in intact ewes and ovariectomized ewes treated with steroids to induce an artificial follicular phase (model ewes). Transport caused a greater delay in the onsei' of the LH surge in nine intact ewes than it did in ten ovariectomized ewes (intact: $41.0 \pm 0.9 \mathrm{~h}$ versus $48.3 \pm 0.8 \mathrm{~h}, P<0.02$; ovariectomized model: $40.8 \pm 0.6 \mathrm{~h}$ versus $42.6 \pm 0.5 \mathrm{~h}$, $P<0.02$ ). Disruption of the hypothalamus-pituitary endocrine balance in intact ewes may have reduced gonadotrophin stimulation of follicular oestradiol production which had an additional effect on the LH surge mechanism. In the ovariectomized model ewes, this effect was masked by the exogenous supply of oestradiol. However, in these model ewes, there was a greater suppression of maximum LH surge concentrations (intact controls: $29 \pm 4 \mathrm{ng} \mathrm{ml}^{-1}$ versus intact transported $22 \pm 5 \mathrm{ng} \mathrm{ml}^{-1}, P<0.02$; ovariectomized model controls: $35 \pm 7 \mathrm{ng} \mathrm{ml}^{-1}$ versus model transported $15 \pm 2 \mathrm{ng} \mathrm{ml}^{-1}$, $P<0.02$ ). Subsequent exposure to progesterone for 12 days resulted in the resumption of a normal LH profile in the next follicular phase, indicating that acute stress leads to a temporary endocrine lesion. In four intact ewes transported in the mid-follicular phase, there was a suppression of LH pulse amplitude $\left(0.9 \pm 0.3\right.$ versus $0.3 \pm 0.02 \mathrm{ng} \mathrm{ml}^{-1}$, $P<0.05)$ but a statistically significant effect on pulse frequency was not observed $(2.0 \pm 0.4$ versus $1.7 \pm 0.6$ pulses per $2 \mathrm{~h})$. In conclusion, activation of the hypothalamus-pituitary-adrenal axis by transport in the follicular phase of intact ewes interrupts surge secretion of LH, possibly by interference with LH pulsatility and, hence, follicular oestradiol production. This disruption of gonadotrophin secretion will have a major impact on fertility.
\end{abstract}

\section{Introduction}

We have established that stress in farm animals reduces fertility (Dobson and Smith, 1995) and the aim of this study was to elucidate further the mechanisms involved. Pulses of GnRH secretion and, hence, LH release are normally controlled by increasing amounts of oestradiol produced by ovarian follicles, eventually leading to the LH surge required for ovulation and luteinization (Goodman, 1994).

The precise timing of a stressor relative to the onset of the LH surge is important. Transport in the $2-4 \mathrm{~h}$ period before the onset of the preovulatory LH surge delays the surge, whereas transport 8-10 h before the LH surge has no effect (Dobson and Nanda, 1992; Smart et al., 1994). However, the duration of the spontaneous follicular phase in intact ewes is very variable. Therefore, a model was required in which the stressor could be imposed before a precisely timed LH surge to investigate the effects of transport immediately before this surge. Evans et al. (1994) suggested that ovariectomized ewes treated with

Revised manuscript received 26 November 1998. progesterone followed by increasing numbers of oestradiol implants provide a repeatable model for the follicular phase in intact ewes. Consequently, the present series of experiments was designed to examine whether transport would cause a delay in the LH surge in ovariectomized, steroid-treated model ewes similar to that observed in intact ewes. Furthermore, as LH is secreted in a pulsatile pattern before the surge, thus forming an important impetus for oestradiol production by the growing follicle (Dobson et al., 1997), the pulsatile nature of $\mathrm{GnRH}$ and $\mathrm{LH}$ secretion in intact and model ewes during transport was examined.

\section{Materials and Methods}

\section{Animals and collection of blood samples}

This study was carried out with cross-bred mature ewes weighing between 50 and $75 \mathrm{~kg}$ in a series of experiments during the breeding season. In Expt 1, the ewes were housed loosely together in a barn and guided through a handling 
race to carry out each procedure. In Expt 2, the ewes were kept indoors in single pens, and had visual contact with one another. In both experiments, concentrate feed was provided twice a day; hay and water were available ad libitum.

These experiments began 2 months after the ovaries of half the ewes had been removed under general anaesthesia (a combination of Diazepam $\left(0.5 \mathrm{mg} \mathrm{kg}^{-1} \mathrm{i} . \mathrm{v}\right.$; Phoenix Pharmaceuticals, Gloucester) and Ketaset ( $5.0 \mathrm{mg} \mathrm{kg}^{-1}$ i.v; Fort Dodge Animal Health, Southampton) followed by maintenance on gaseous Halothane (Rhone Merieux, Harlow)) to avoid inflicting pain by transportation on recently ovariectomized animals. A small subcutaneous oestradiol implant $(10 \mathrm{~mm} \times 3.3 \mathrm{~mm})$ was implanted during ovariectomy and remained subcutaneous throughout the study (Ozturk et al., 1998). Artificial oestrous cycles were maintained by administration of luteal concentrations of progesterone using an intra-vaginal device for 10 days (CIDR-G, InterAg, Hamilton; Wheaton et al., 1993). Twentytwo hours after progesterone removal, two large oestradiol implants $(30 \mathrm{~mm} \times 3.3 \mathrm{~mm})$ were inserted subcutaneously, followed $10 \mathrm{~h}$ later by a further two $30 \mathrm{~mm}$ implants. All the large oestradiol implants were removed $66 \mathrm{~h}$ after progesterone removal and a new CIDR-G was inserted to begin the next cycle. Hereafter, ewes treated in this way are referred to as ovariectomized model ewes.

In intact ewes, oestrous cycles were synchronized with a CIDR-G inserted for 10 days and, on the day of progesterone removal, $250 \mathrm{mg}$ of the synthetic prostaglandin, cloprostenol (Estrumate; Coopers Animal Health Ltd, Sandwich), was given intramuscularly. For the cycle immediately before each experiment, two CIDR-Gs were inserted simultaneously for 10 days in intact ewes, because, from previous experience (Kelly et al., 1996), greater synchrony of the LH surge is achieved using two devices rather than one in intact ewes. Only one CIDR-G was used in the ovariectomized model ewes.

Before each experiment, all ewes were accustomed to human contact and mock sampling procedures for at least 10 days to minimize the effect of this stressor during the experimental period. One day before each experiment, indwelling catheters were inserted into the jugular vein under local anaesthesia in all ewes and catheter patency was maintained with heparinized saline $\left(100 \mathrm{iu} \mathrm{ml}^{-1}\right)$. Blood samples $(4 \mathrm{ml})$ were collected in heparinized tubes and immediately centrifuged at $1000 \mathrm{~g}$ for $20 \mathrm{~min}$. Plasma was stored at $-15^{\circ} \mathrm{C}$ until analysed.

\section{Transport}

In Expt 1, when indicated, groups of 20 ewes were transported untethered in an enclosed truck $(4 \mathrm{~m} \times 2 \mathrm{~m})$ along metalled roads for $4 \mathrm{~h}$. In Expt 2, groups of two or four ewes were restrained in individual metabolism crates $(1.5 \mathrm{~m} \times 0.5 \mathrm{~m})$ to facilitate portal blood sampling. Blood samples were collected during transport without the vehicle stopping. No physical injuries were sustained in either experiment during transport. After transport, the ewes were returned to the original housing and sampling continued. The different parts of each experiment were carried out sequentially because removing animals for transport would disturb control animals not being transported. In Expt 1, the timing of LH surges in control cycles was monitored before and after the period in which transport occurred to confirm the validity of this procedure. The same ewes were used in each part of each experiment to reduce the effect of variation among individuals. Transport began at the same time of day (noon) in each experiment to avoid any complication of possible diurnal effects.

\section{Experimental design}

The experimental protocol is summarized (Fig. 1).

Experiment 1. During Expt 1a (control), ewes were divided into intact ( $n=10$ ) or ovariectomized model ( $n=10$ ) groups and monitored during the synchronized, or simulated, follicular phase after progesterone removal. In Expt 1b, the same ewes in the same groups were transported for $4 \mathrm{~h}$ from 38 to $42 \mathrm{~h}$ after progesterone withdrawal. One oestrous cycle later, in Expt 1c, the protocol for Expt 1a was repeated. In all parts of Expt 1, blood samples were collected at $2 \mathrm{~h}$ intervals from 20 to $66 \mathrm{~h}$ after progesterone withdrawal.

Experiment 2. The initial aim of Expt 2 was to analyse the effect of transport on GnRH secretion. Consequently, 2 weeks before blood sampling, all ewes had a portal blood collection cannula inserted under ketamine-halothane anaesthesia. Unfortunately, owing to assay difficulties in the laboratory, it was not possible to measure GnRH in the portal samples. However, data were obtained from peripheral LH measurements.

Four intact and three ovariectomized model ewes (chosen from those used in Expt 1 with the closest synchrony of LH surges on repeated occasions) were monitored during control and transported follicular phases (Expt 2a,b), as described in Expt 1, in a cross-over design with more frequent blood sample collection (every $10 \mathrm{~min}$ ) from 36 to 44 or $48 \mathrm{~h}$ after progesterone withdrawal around an early period of transport (38-42 h).

In Expt $2 \mathrm{c}$ and $\mathrm{d}$, the same four ovariectomized model ewes were treated as in Expt $2 a$ and b, but the period of transport began $7 \mathrm{~h}$ later (that is, from 45 to $49 \mathrm{~h}$ after progesterone withdrawal), and blood samples were taken every $10 \mathrm{~min}$ from 44 to $60 \mathrm{~h}$.

\section{Hormone analysis}

For each sheep, samples obtained within each experiment were analysed in the same assay. Methods characterized and verified in our laboratory were used to measure LH (Dobson and Ward, 1977) and cortisol (Alam et al., 1986). For pulsatile LH patterns, samples were analysed using $200 \mathrm{ml}$ of plasma and the results were expressed as ng equivalents of NIAMDD ovine LH $21 \mathrm{ml}^{-1}$ plasma. Interassay and intra-assay coefficients of variation for LH and cortisol were $<7 \%$ and $<7.5 \%$, respectively, with minimum detectable quantities of $0.3 \mathrm{ng} \mathrm{m}^{-1}$ and $0.4 \mathrm{ng} \mathrm{m}^{-1}$, respectively, and precision in the mid-range of the standard curve of 0.1 and $0.2 \mathrm{ng} \mathrm{ml}^{-1}$, respectively. 
Experiment 1

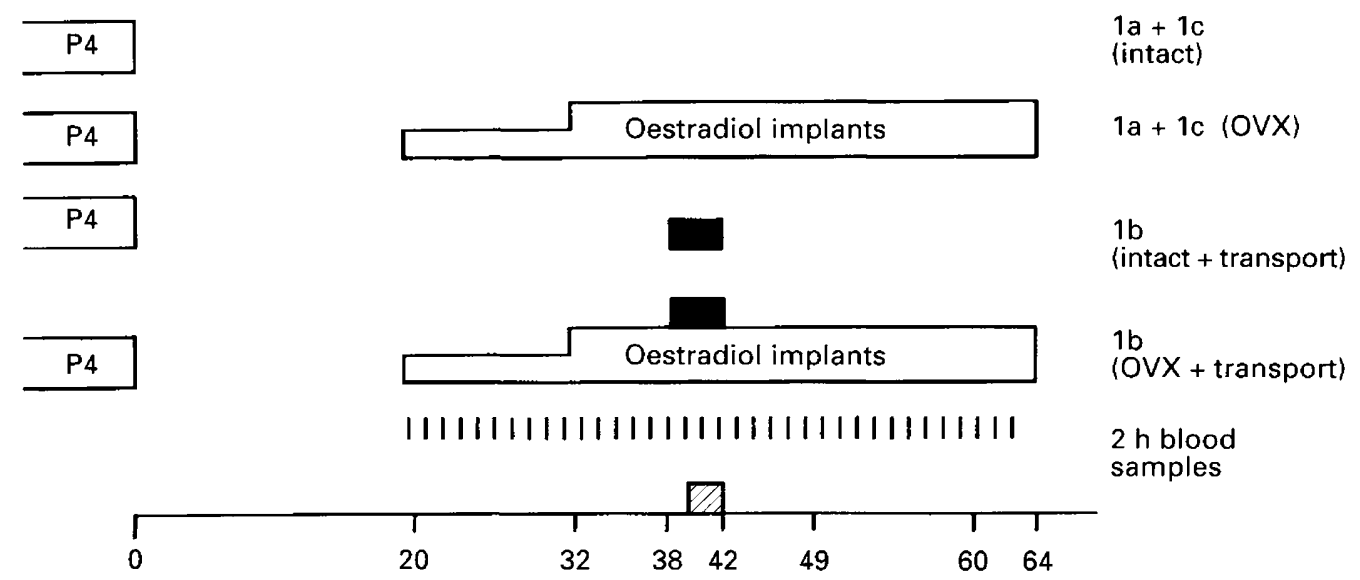

Experiment 2

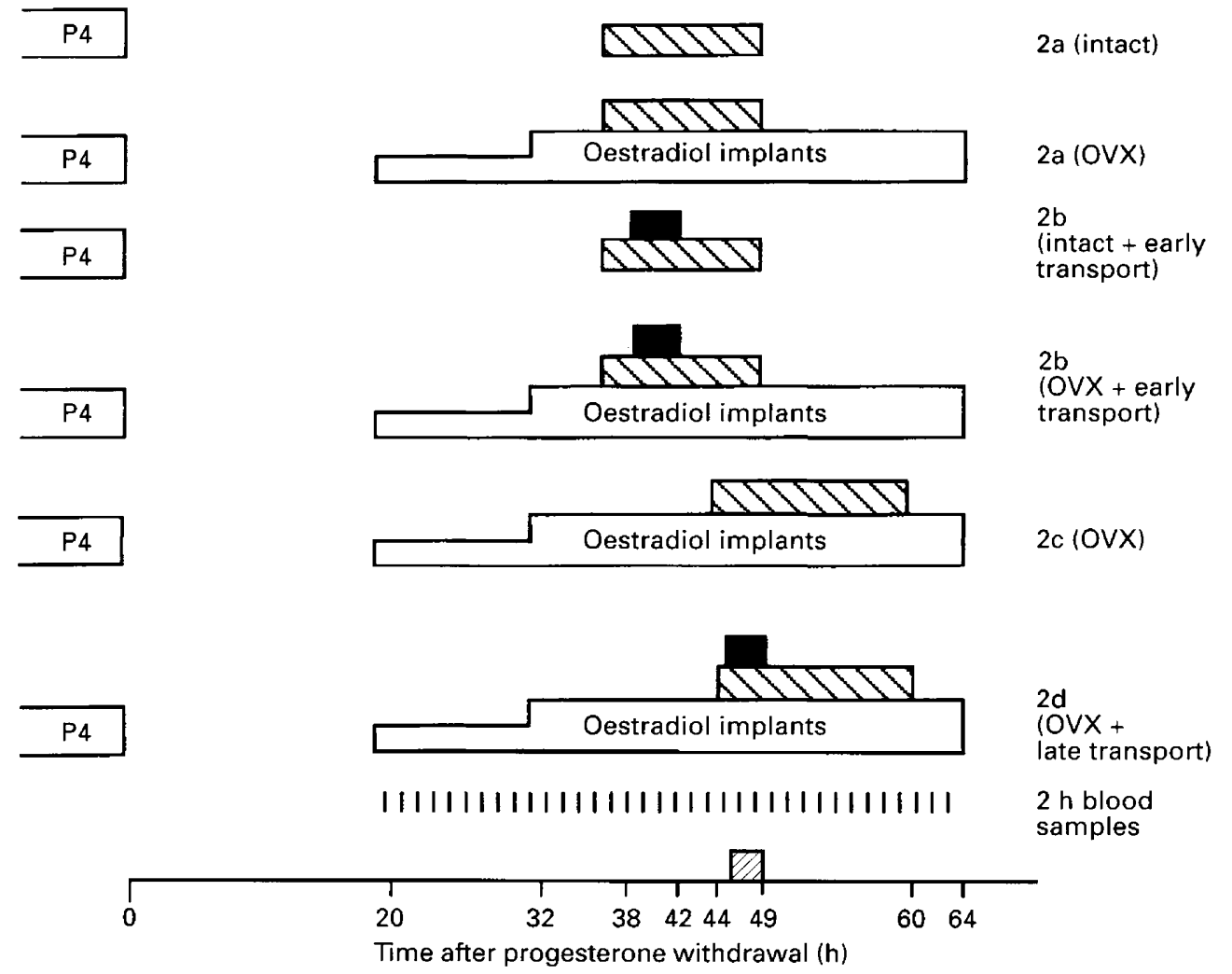

Fig. 1. Summary of experimental protocol after oestrous synchronization with progestin sponges for 10 days (P4). In Expt 1, groups of ten intact or ovariectomized ewes treated with oestradiol implants $(\square)$ were transported for $4 \mathrm{~h}(\boldsymbol{\square})$ or acted as controls in the cycle before or after (Expt 1a and c) the transported cycle (Expt 1b). Blood sampling after progestin withdrawal took place every $2 \mathrm{~h}$ as indicated by vertical lines around the time of the expected onset of the LH surge ( $\square)$. In Expt 2, groups of three or four ewes, either intact or ovariectomized and treated with oestradiol implants $(\square)$, all with a portal sampling apparatus inserted, were transported either early (Expt $2 \mathrm{a}$ and b) or late (Expt $2 \mathrm{c}$ and d) for $4 \mathrm{~h}(\boldsymbol{\square})$ or acted as controls. Additional

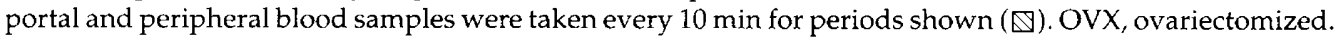

\section{Statistical analysis}

Results are expressed as mean \pm SEM. Data obtained from each control experiment and the transport experiment (within the same groups) were compared by ANOVA for repeated measures, followed by Student's two-tail paired $t$ test with significance assigned at $P<0.05$. The same ewes were used in control and transport experiments within the same groups (and in both Expts 1 and 2 for direct comparison) so the results were compared on a within-ewe 
basis, each sheep serving as its own control, to minimize the effects of between-animal variation. However, post hoc comparisons between the different groups, within or between Expts 1 and 2, for LH and cortisol were made by an unpaired Student's $t$ test.

In Expt 1, the occurrence of the LH surge was defined as at least two consecutive samples (at $2 \mathrm{~h}$ intervals) containing $>5 \mathrm{ng} \mathrm{LH} \mathrm{ml}{ }^{-1}$, with the time of first sample $>5 \mathrm{ng} \mathrm{ml}^{-1}$ being designated as the onset time of the LH surge. The highest value recorded during the L.H surge was defined as the surge maximum, and the time between the first and last sample $>5 \mathrm{ng} \mathrm{ml}^{-1}$ was used to define the duration of the LH surge.

In Expt 2, a presurge baseline was defined as the average of all values in $5 \mathrm{~h}$ period (or as long as available up to $5 \mathrm{~h}$ ) representative of the presurge secretion for a particular ewe. The onset of the LH surge was defined as the first sample in a series lasting at least $1 \mathrm{~h}$ and increasing at least two times above the average of the presurge baseline; this value was always 2 SD above the presurge average.

The LH pulse data from Expts $2 a$ and $b$ were analysed with the Munro algorithm (Taylor, 1987), which is a modified version of the Pulsar algorithm (Merriam and Wachter, 1982). The smoothing windows, which define the number of samples used to calculate the moving averages, were set at $120 \mathrm{~min}$ for the $2 \mathrm{~h}$ periods and $240 \mathrm{~min}$ for the $4 \mathrm{~h}$ periods analysed. The nadir and minimum pulse interval windows were each set at $20 \mathrm{~min}$. The rise threshold, the minimum height to which a peak must increase above nadir to be accepted, was set at $1.0 \mathrm{sD}$. The G parameters (G1-G5) were $3.98,2.40,1.68,1.24$ and 0.93 ; these values give a $5 \%$ false positive error rate. The $\mathrm{G}$ parameters are the number of SD by which a hormone peak value (composed of one-five samples) must exceed the baseline to be accepted as a pulse. The Baxter parameters, describing the parabolic relationship between the concentration of a hormone in a sample and the SD (assay variation) about that concentration, were $0.013\left(b_{1}\right.$, the $y$ intercept), $0.019\left(\mathrm{~b}_{2}\right.$, the $x$ coefficient) and $0.003\left(\mathrm{~b}_{3}\right.$, the $x^{2}$ coefficient). The nadir, amplitude and area for each pulse and the mean nadir, mean pulse amplitude, mean pulse area and mean pulse interval for each ewe with or without transport were calculated by the program. Treatment effects, comparing values within each ewe with or without transport, were identified by Student's paired $t$ test. Values were transformed before statistical analysis ( $\log _{10}$ transformed for nadir, pulse area, mean concentration and pulse amplitude, and square root transformed for pulse frequency).

\section{Results}

\section{$L H$}

Experiment 1. There were no differences in the characteristics of the LH surge between the control experiments carried out before or after the transport experiment (Expt 1a versus 1c; Table 1). In the intact animals, transport for $4 \mathrm{~h}$ starting $38 \mathrm{~h}$ after progesterone withdrawal resulted in one ewe not having an LH surge observed, and an average $7.3 \mathrm{~h}$ delay in surge onset in those ewes that did have a surge (comparing Expt $1 \mathrm{a}$ with 1b; Table 1). All the ovariectomized model ewes had an LH surge but the onset was delayed by only approximately $2.0 \mathrm{~h}$. The duration of the LH surge was not affected by transport, but the LH surge maximum was lowered by transport in both intact and ovariectomized ewes, with a greater effect in ovariectomized ewes (average decrease of 7 versus $20 \mathrm{ng} \mathrm{ml}^{-1}$; comparing Expt 1a with 1b; Table 1)

Experiment 2. Insertion of portal collection apparatus in the control groups (intact and ovariectomized model) resulted in later onset of the LH surge after progesterone withdrawal compared with the same animals used in Expt 1 (intact: $41.0 \pm 0.9$ versus $60.0 \pm 6.7 \mathrm{~h}, \quad P<0.01$; ovariectomized model: $40.8 \pm 0.6$ versus $50.6 \pm 1.1 \mathrm{~h}, P<0.05$ ).

The onset of the LH surge was monitored in the four intact control animals, but sampling stopped before the end of the surge and no further surge data analyses were performed. In two of the three intact animals that were transported in the early period for $4 \mathrm{~h}$ starting $38 \mathrm{~h}$ after progesterone withdrawal, the onset of the $\mathrm{LH}$ surge was not observed before the end of sampling. However, there was no delay in the one animal in which a surge was observed (Table 2).

Table 1. Characteristics (mean \pm SEM) of the LH surge in intact or ovariectomized model ewes with (Expt 1b) or without (Expts 1a,c) transport from 38 to $42 \mathrm{~h}$ after progesterone withdrawal

\begin{tabular}{|c|c|c|c|c|}
\hline & $\begin{array}{l}\text { Time to LH surge onset } \\
\text { after progesterone (h) }\end{array}$ & $\begin{array}{c}\text { LH surge } \\
\text { duration }(\mathrm{h})\end{array}$ & $\begin{array}{c}\text { Maximum } \\
\left.\text { LH (ng mil }{ }^{-1}\right)\end{array}$ & $\begin{array}{c}\text { Ewes with LH } \\
\text { surge }\end{array}$ \\
\hline \multicolumn{5}{|l|}{ Intact ewes } \\
\hline Expt 1a & $41.0 \pm 0.9^{a}$ & $8.4 \pm 0.9$ & $29 \pm 4^{c}$ & $10 / 10$ \\
\hline Expt 1b & $48.3 \pm 0.8^{b}$ & $6.8 \pm 1.6$ & $22 \pm 5^{\mathrm{d}}$ & $9 / 10$ \\
\hline Expt 1c & $40.5 \pm 0.9^{a}$ & $8.3 \pm 0.9$ & $32 \pm 8^{c}$ & $9 / 10$ \\
\hline \multicolumn{5}{|c|}{ Ovariectomized model ewes } \\
\hline Expt 1a & $40.8 \pm 0.6^{\mathrm{c}}$ & $6.4 \pm 0.4$ & $35 \pm 78$ & $10 / 10$ \\
\hline Expt 1b & $42.6 \pm 0.5^{\mathfrak{k}}$ & $5.8 \pm 0.7$ & $15 \pm 2^{\mathrm{h}}$ & $10 / 10$ \\
\hline Expt 1c & $38.4 \pm 1.2^{\mathrm{c}}$ & $7.3 \pm 0.9$ & $30 \pm 6^{g}$ & $10 / 10$ \\
\hline
\end{tabular}

Within a column for intact or ovariectomized ewes, values with different superscripts differ significantly $(P<0.02 ;$ Student's paired $t$ test).

In one intact ewe in Expt 1b and 1c, an LH surge was not observed by the end of the sampling period, so data from this ewe were excluded from all statistical analysis. 
Table 2. Characteristics of the LH surge in intact or ovariectomized model control ewes (Expts 2a and 2c) or those transported from 38 to $42 \mathrm{~h}$ (Expt 2b) or 45 to $49 \mathrm{~h}$ (Expt 2d) after progesterone withdrawal

\begin{tabular}{|c|c|c|c|c|}
\hline & $\begin{array}{l}\text { Time to LH surge onset } \\
\text { after progesterone }(\mathrm{h})\end{array}$ & $\begin{array}{c}\text { LH surge } \\
\text { duration (h) }\end{array}$ & $\begin{array}{l}\text { Maximum } \\
\mathrm{LH}\left(\mathrm{ng} \mathrm{ml} \mathrm{m}^{-1}\right)\end{array}$ & $\begin{array}{c}\text { Ewes with LH } \\
\text { surge }\end{array}$ \\
\hline \multicolumn{5}{|l|}{ Intact ewes } \\
\hline Expt $2 a$ (control) & $64,50,64,62$ & Incomplete & Incomplete & $4 / 4$ \\
\hline Expt $2 b$ (transport) & $50,-,-$ & Incomplete & Incomplete & $1 / 3$ \\
\hline \multicolumn{5}{|c|}{ Ovariectomized model ewes } \\
\hline Expt 2a (control) & $50,50,52$ & $10,8,8$ & $10,19,8$ & $3 / 3$ \\
\hline Expt $2 b$ (transport) & $50,52,48$ & $10,10,8$ & $5,19,28$ & $3 / 3$ \\
\hline Expt 2c (control) & $48,48,50,45$ & $9,7,8,6$ & $40,28,75,13$ & $4 / 4$ \\
\hline Expt 2d (transport) & $52,46,47,52$ & $7,6,8,8$ & $13,4,75,5$ & $4 / 4$ \\
\hline
\end{tabular}

Group sizes are small, hence values are shown for individual animals (in the same order each time). Sampling of the intact ewes stopped before the LH surge was complete.

All the ovariectomized model ewes had an LH surge but, because of the small number of animals studied, there was no statistical evidence of a delay in onset when the ewes were transported for $4 \mathrm{~h}$ in the early period from $38 \mathrm{~h}$ after progesterone withdrawal (Expt 2a,b; Table 2). The other characteristics of the LH surge were also unaltered by transport at this time.

When the ovariectomized model ewes were transported for $4 \mathrm{~h}$ in the late period from $45 \mathrm{~h}$ after progesterone withdrawal, the timing of the $\mathrm{LH}$ surge was delayed by transport in two ewes for 4 and $7 \mathrm{~h}$, respectively, but not in the remaining two ewes. Two of the four animals initiated an LH surge during the period of transport and so it was not possible to assess the effect of transport on pulse characteristics. In three of the four ewes, the LH surge maximum was lower than the surge maximum in nontransported ewes (Fig. 2; Table 2).

Compared with values for the $2 \mathrm{~h}$ period before transport, LH pulse amplitude was suppressed in intact ewes by early transport from 38 to $42 \mathrm{~h}$ after progesterone withdrawal $\left(0.9 \pm 0.3\right.$ versus $0.3 \pm 0.02 \mathrm{ng} \mathrm{ml}^{-1}, \quad P<0.05 ;$ Table 3, exemplified in Fig. 3), although no effect of transport on pulse amplitude was observed in the ovariectomized model ewes. No effects of transport on pulse frequency were observed in either group of ewes; in intact ewes, there were $2.0 \pm 0.4$ and $1.7 \pm 0.6$ pulses per $2 \mathrm{~h}$ before and during transport, respectively.

\section{Cortisol}

There was a similar marked increase in cortisol secretion during transport in all intact or ovariectomized animals, with no difference in response between the two groups of animal $(P>0.1$ for area under curve in Fig. 4$)$.

\section{Discussion}

Transport for $4 \mathrm{~h}$ in the late follicular phase caused a greater delay in the onset of the LH surge in intact ewes than in ovariectomized model ewes $(7.3$ versus $2.0 \mathrm{~h}$ ). This finding

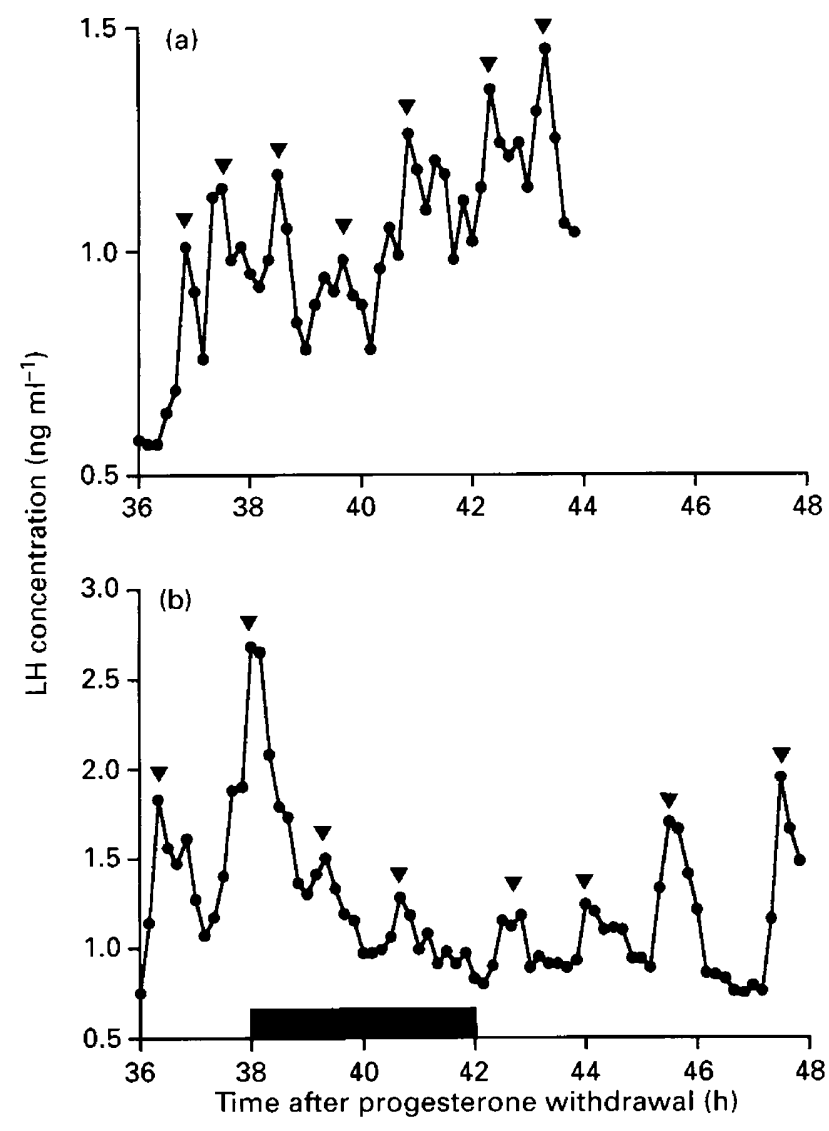

Fig. 2. Concentration of $\mathrm{LH}$ in the same ovariectomized model ewe with a portal cannula with (a) or without (b) transport (Expt $2 c$ and d) for the time shown ( $\square$ ) in the period after progesterone withdrawal. Pulses are indicated by inverted arrow heads.

indicates that the steroid replacement regimen did not exactly mimic the intact hormonal situation, and that the effects of stress on the hypothalamus-pituitary axis depend on disrupting a very delicate endocrine balance. The steroid milieu provided by the replacement protocol resulted in a more robust stimulus to the hypothalamus-pituitary than that in intact animals (also recognized by Karsch et al., 1980), 
Table 3. Mean amplitude ( \pm SEM, ng ml-1) and average frequency ( \pm SEM, pulses per $2 \mathrm{~h}$ ) for $2 \mathrm{~h}$ before, during and after transport of four intact and three ovariectomized model ewes transported either early (38-42 $\mathrm{h}$ after progesterone withdrawal; Expts $2 \mathrm{a}$ and $2 \mathrm{~b}$ ) or later (45-49 $\mathrm{h}$ after progesterone withdrawal; Expts $2 \mathrm{c}$ and $2 \mathrm{~d}$ )

\begin{tabular}{|c|c|c|c|c|c|c|}
\hline & \multicolumn{3}{|c|}{ Mean amplitude $\left(\mathrm{ng} \mathrm{m}^{-1}\right)$} & \multicolumn{3}{|c|}{ Mean frequency (pulses per $2 \mathrm{~h}$ ) } \\
\hline & Before & During & After & Before & During & After \\
\hline \multicolumn{7}{|l|}{ Intact ewes } \\
\hline Expt 2a (control) & $0.6 \pm 0.2$ & $0.5 \pm 0.3$ & $0.5 \pm 0.1$ & $2.5 \pm 0.6$ & $2.5 \pm 0.2$ & $1.5 \pm 0.3$ \\
\hline Expt $2 \mathrm{~b}$ (transport) & $0.9 \pm 0.3$ & $0.3 \pm 0.1$ & $0.2 \pm 0.1$ & $2.0 \pm 0.4$ & $1.7 \pm 0.6$ & $2.0 \pm 0.4$ \\
\hline \multicolumn{7}{|c|}{ Ovariectomized model ewes } \\
\hline Expt $2 a$ (control) & $0.2 \pm 0.1$ & $0.4 \pm 0.1$ & $0.3 \pm 0.2$ & $2.0 \pm 0.0$ & $1.5 \pm 0.3$ & $2.7 \pm 0.3$ \\
\hline Expt $2 b$ (transport) & $0.2 \pm 0.1$ & $0.1 \pm 0.1$ & $0.2 \pm 0.1$ & $1.0 \pm 0.6$ & $1.6 \pm 0.6$ & $1.7 \pm 0.3$ \\
\hline
\end{tabular}

Transport lasted for $4 \mathrm{~h}$ but the above figures have been calculated on a $2 \mathrm{~h}$ basis for direct comparison with the $2 \mathrm{~h}$ periods before and after transport.
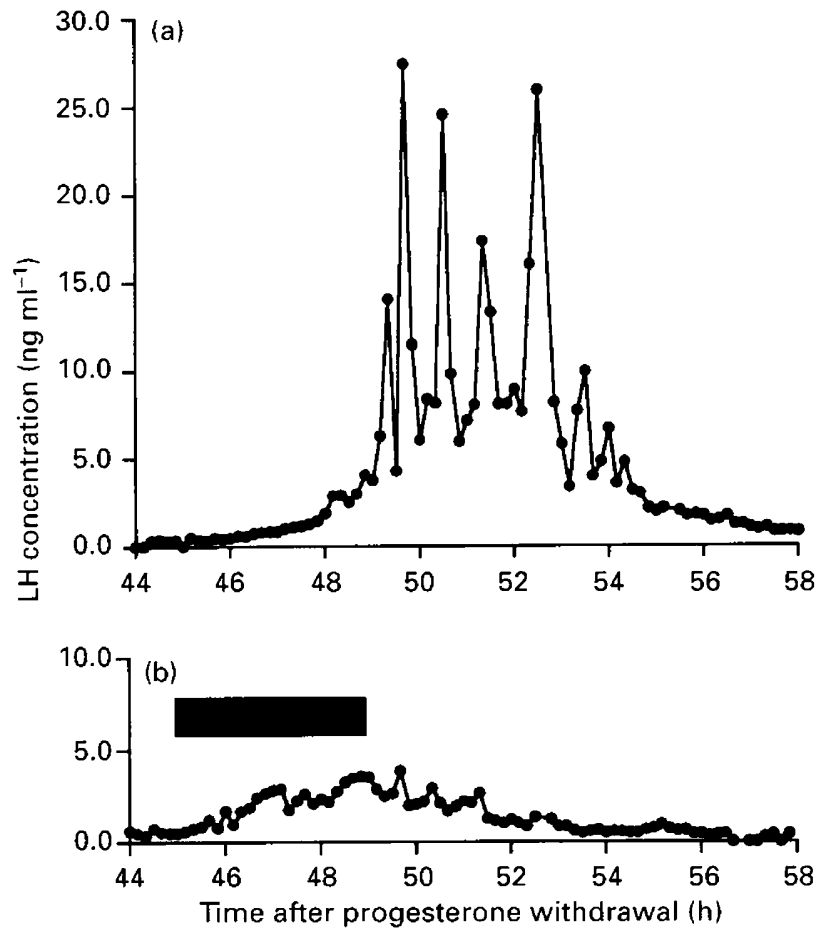

Fig. 3. Concentration of $\mathrm{LH}$ in the same intact ewe with a portal cannula with (a) or without (b) transport (Expt $2 a$ and b) for the time shown ( $\square$ in the period after progesterone withdrawal.

in spite of peripheral oestradiol concentrations similar to those in intact ewes (Evans et al., 1994). The oestradiol implants deliver a constant supply of steroid, unlike the pulsatile oestradiol pattern that shadows LH pulses in intact ewes (Campbell et al., 1990). If LH pulsatility is disrupted, oestradiol secretion will cease within hours, thus removing the further stimulus for the LH surge (Dobson et al., in press). Thus, stress-induced suppression of LH pulses will contribute to lowered oestradiol concentrations (and hence a marked

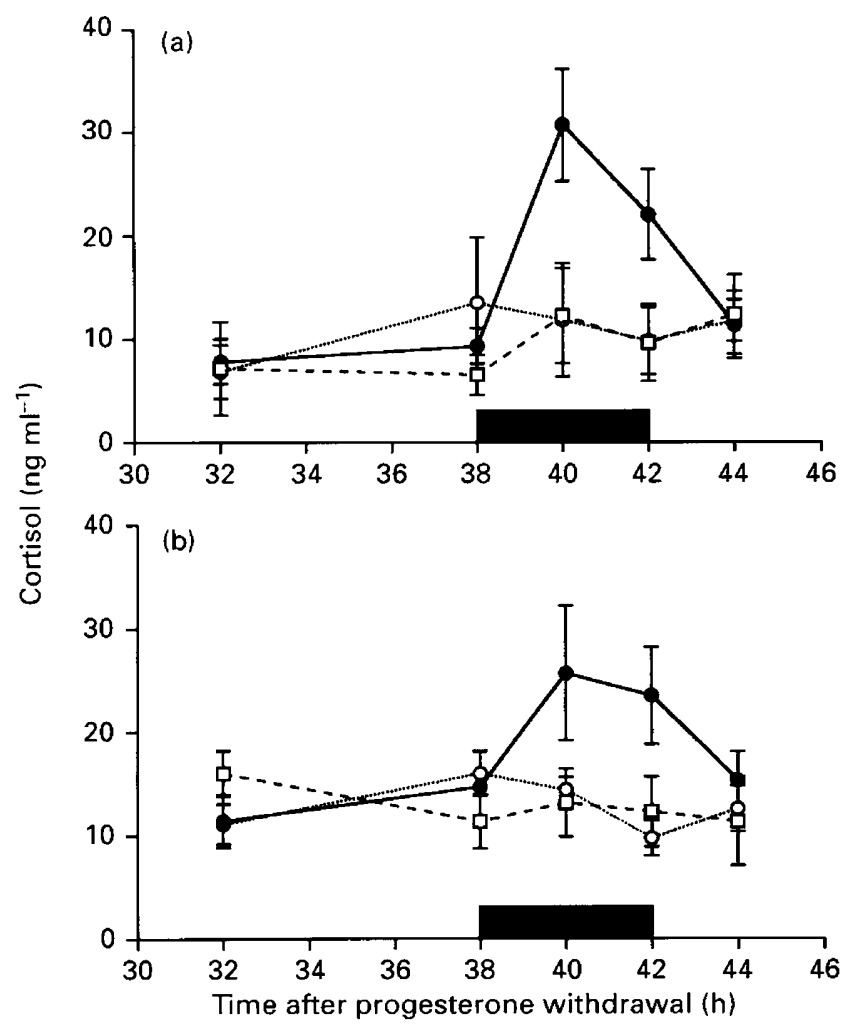

Fig. 4. Concentration of cortisol in an intact (a) and ovariectomized (b) ewe with or without transport $(\square$, Expt 1a;, Expt 1b; $\bigcirc$, Expt 1c) for the time shown ( $\boldsymbol{\square}$ ) in the period after progesterone withdrawal.

delay in the LH surge) in contrast to the constant supply of oestradiol that will continue from the implants in the model ewes. Consequently, transport disrupted the message for initiation of the LH surge to a greater extent in the intact ewes than it did in the ovariectomized model ewes, although maximum LH surge values were suppressed in both groups. Exposure to progesterone for 12 days after disruption of the LH surge at the end of the follicular phase resulted in a normal LH profile in the subsequent follicular phase. 
Therefore, the lesion produced by acute stress in the follicular phase was not permanent.

The presence of the portal blood collection cannula resulted in a delay in the onset of the LH surge in control animals (previously recognized by Moenter et al., 1990, 1991), but there was no firm evidence of a further delay imposed by transport imposed as early as $2 \mathrm{~h}$ before the expected onset of the surge. Transport of ovariectomized model ewes nearer the onset of the surge again resulted in lower maximum LH values in animals with this preparation. Although this result could have been due to variable portal lesion sites, this is unlikely as the observation is supported by results from Expt 1 , and by similar evidence from Smart et al. (1994) that transport reduced the maxima of oestradiol-induced LH surges in postpartum ewes. Kaynard et al. (1988) and Evans et al. (1995) have established that a precise pattern of GnRH secretion is essential for initiation of a normal LH surge and evidence from LH values in the present study indicates that, if this pattern is interrupted by a stressor, the LH surge will be both delayed and of lower magnitude.

The suppression of LH pulse amplitude in intact ewes transported in the mid-follicular phase concurs with observations in ovariectomized ewes after restraint, insulininduced hypoglycaemia or endotoxin administration (Rasmussen and Malven, 1983; Clarke et al., 1990; Battaglia et al., 1997). The reduction in amplitude could be due to a direct effect at the pituitary, as there is a reduction in the amount of $\mathrm{LH}$ released by $\mathrm{GnRH}$ in pituitary tissue exposed to adrenocorticotrophic hormone (ACTH) in vitro (Phogat et al., 1997a). However, the reduction in LH pulse amplitude could be indicative of an effect within the hypothalamus resulting in less GnRH being secreted (confirmed by Battaglia et al., 1997), which could also decrease surge peak values, as discussed above, as reducing doses of GnRH depress LH synthesis (Leung et al., 1987; Kaiser et al., 1997). In addition, there is an increase in basal GnRH secretion between pulses, especially 2-4 h before the onset of the LH surge (Evans et al., 1995). It is possible that this basal GnRH is also important for pituitary LH synthesis and that this will be disrupted if GnRH secretion is reduced by stressors.

The present study failed to reveal a statistical effect of transport on LH pulse frequency in the mid-follicular phase, as has been reported by Phogat et al. (1999). This result may have been due to the short $4 \mathrm{~h}$ period of sample collection before transport (dictated by the portal blood sampling protocol) as well as the discontinuous nature of the pulses that only occurred approximately once per hour.

There was insufficient evidence for a delayed LH surge in the ovariectomized portal model ewes after transport at either $8-12 \mathrm{~h}$ or $0-4 \mathrm{~h}$ before the expected onset. In fact, in two of the four ewes, the LH surge began during transport, emphasizing the fact that the replacement steroid dose did not replicate precisely the delicate balance that occurs in intact ewes. Oestradiol has direct effects at the pituitary, leading to an LH surge (Kaynard et al., 1988; Clarke et al., 1989). In the ovariectomized model, oestradiol was supplied by the implants and pituitary activation by this, along with pulsatile LH for the previous $24-48 \mathrm{~h}$, may have been sufficient to provoke the initiation of LH surge secretion.

Exactly how LH and GnRH secretion are influenced by stressors is still not known. Cortisol secretion increased equally in intact and ovariectomized animals in this experiment, and there is evidence for increased corticotrophinreleasing hormone, arginine vasopressin and $\mathrm{ACTH}$ secretion during transport (Smith et al,, 1997). However, the mechanism(s) by which activation of the hypothalamuspituitary-adrenal interferes with the reproductive hypothalamus-pituitary axis in sheep is not yet clear (for review, see Phogat et al., 1997b).

In conclusion, transport of intact ewes for $4 \mathrm{~h}$ in the hours leading up to the LH surge, reduced pulsatile and surge LH secretion. A reduction in LH pulsatility will lead to poorer follicular development and decreased oestradiol synthesis which, subsequently, will weaken the endocrine messages that initiate the LH surge and, thus, have a major impact on fertility. The effects were not so marked in ovariectomized model ewes to which steroids were constantly supplied by the chosen replacement regimen.

The authors are grateful to the Association of Commonwealth Universities for a fellowship to P. B. Phogat; to the Wellcome Trust for a Fellowship to R. F. Smith; to H. Purcell, T. Roscoe, V. Kelly and S. Deacon for their technical help; to R. Bass, N. Jones and his staff for care of the sheep; and to NIAMDD, Bethesda, MD for gonadotrophin assay reagents.

\section{References}

Alam MGS, Dobson H and Fitzpatrick RJ (1986) Endocrine response to different doses of ACTH in cows British Veterinary Journal 142 239-245

Battaglia DF, Bowen JM, Krasa HB, Thrun LA, Viguie C and Karsch FJ (1997) Endotoxin inhibits the neuroendocrine axis while stimulating adrenal steroids: a simultaneous view from hypophyseal portal and peripheral blood Endocrinology 138 4273-4281

Campbell BK, McNeilly AS, Picton HM and Baird DT (1990) The effect of a potent gonadotropin-releasing hormone antagonist on ovarian secretion of oestradiol, inhibin and androstenedione and the concentration of $\mathrm{LH}$ and FSH during the follicular phase of the sheep oestrous cycle Journal of Endocrinology 126 377-384

Clarke IJ, Cummins JT, Jenkin $\mathbf{M}$ and Phillips DJ (1989) The oestrogen-induced surge of LH requires a signal pattern of gonadotropin-releasing hormone input to the pituitary gland in the ewe Journal of Endocrinology 122 127-134

Clarke IJ, Horton RJE and Doughton BW (1990) Investigation of the mechanism by which insulin-induced hypoglycemia decreases luteinizing hormone secretion in ovariectomized ewes Endocrinology 127 1470-1476

Dobson H (1987) Effect of transport stress on luteinizing hormone released by GnRH Acta Endocrinologica (Copenhagen) 115 63-66

Dobson $\mathbf{H}$ and Nanda AS (1992) Reliability of cyst diagnosis and effect of energy status on $\mathrm{LH}$ released by oestradiol or GnRH in cows with ovarian cysts Theriogenology $37465-472$

Dobson $\mathbf{H}$ and Smith RF (1995) Stress and reproduction in farm animals Journal of Reproduction and Fertility Supplement 49 451-461

Dobson H and Ward WR (1977) Alterations in plasma gonadotrophin patterns caused by sodium pentabarbitone in ewes at oestrus and in anoestrous ewes after infusion of oestradiol Journal of Endocrinology 75 109-118

Dobson H, Campbell BK and Scaramuzzi RJ (1997) Use of a GnRH antagonist in conjunction with low amplitude, high frequency LH pulses to induce follicular growth without an LH surge and ovulation in ewes Animal Reproduction Science 46 213-222

Dobson H, Campbell BK, Scaramuzzi RJ and Baird DT Effect of reducing LH pulse frequency and amplitude on ovarian oestradiol production in the ewe Journal of Reproduction and Fertility Supplement 54 (in press)

Evans NP, Dahl GE, Glover BH and Karsch FJ (1994) Central regulation of pulsatile gonadotropin-releasing hormone $(\mathrm{GnRH})$ secretion by estradiol during the period leading up to the preovulatory GnRH surge in the ewe Endocrinology 134 1806-1811

Evans NP, Dahl GE, Mauger D and Karsch FJ (1995) Estradiol induces both 
qualitative and quantitative changes in the pattern of gonadotropinreleasing hormone secretion during the presurge period in the ewe Endocrinology 136 1603-1609

Goodman RL (1994) Neuroendocrine control of the ovine estrous cycle. In The Physiology of Reproduction 2nd Edn Vol. 2 pp 659-709 Eds E Knobil and JD Neill. Raven Press, New York

Kaiser UB, Jakubowiak A, Steinberger A and Chin WW (1997) Differential effects of gonadotropin-releasing hormone (GnRH) pulse frequency on gonadotropin subunit and GnRH receptor messenger ribonucleic acid levels in vitro. Endocrinology 138 1224-1231

Karsch FJ, Legan SJ, Ryan KD and Foster DL (1980) Importance of estradiol and progesterone in regulating LH secretion and estrous behaviour during the sheep estrous cycle Biology of Reproduction 23 404-413

Kaynard AH, Malpaux B, Robinson JE, Wayne NL and Karsch FJ (1988) Importance of pituitary and neural actions of estradiol in induction of the luteinizing hormone surge in the ewe Neuroendocrinology 48 296-303

Kelly VM, Phogat JB, Smith RF, Deacon SE and Dobson H (1996) Pretreatment progesterone dose on the timing of the $\mathrm{LH}$ surge in ewes Acta Neurobiologiae Exptalis $\mathbf{5 6} 845$

Leung K, Kaynard AH, Negrini BP, Kim KE, Maurer RA and Landefeld TD (1987) Differential regulation of gonadotropin subunit messenger ribonucleic-acids by gonadotropin-releasing hormone pulse frequency in ewes Molecular Endocrinology 1 724-728

Merriam GR and Wachter KW (1982) Algorithms for the study of episodic hormone secretion American fournal of Physiology 243 E310-E318

Moenter SM, Caraty A and Karsch FJ (1990) The estradiol-induced surge of gonadotropin-releasing hormone in the ewe Endocrinology 127 1375-1384

Moenter SM, Caraty A, Locatelli A and Karsch FJ (1991) Pattern of gonadotropin-releasing hormone $(\mathrm{GnRH})$ secretion leading up to ovulation in the ewe - existence of a preovulatory GnRH surge Endocrinology 129 $1175-1182$

Ozturk M, Smith RF and Dobson H (1998) Effect of prolonged exposure to oestradiol on subsequent LH secretion in ewes Journal of Reproduction and Fertility 114 1-9

Phogat JB, Smith RF and Dobson H (1997a) Effect of adrenocorticotrophic hormone on gonadotrophin releasing hormone-induced luteinizing hormone secretion in vitro. Animal Reproduction Science 48 53-65

Phogat PB, Smith RF and Dobson H (1997b) The influence of stress on neuroendocrine control of the hypothalamic-pituitary-ovarian axis Veterinary Bulletin $67553-567$

Phogat PB, Smith RF and Dobson H (1999) Effect of transport on pituitary responsiveness to exogenous pulsatile $\mathrm{GnRH}$ and oestradiol induced $\mathrm{LH}$ release in intact ewes Journal of Reproduction and Fertility 116 9-18

Rasmussen DD and Malven PV (1983) Effects of confinement stress on episodic secretion of LH in ovariectomised sheep Neuroendocrinology 36 392-396

Smart D, Forhead AJ, Smith RF and Dobson H (1994) Transport stress delays the oestradiol-induced LH surge by a non-opiodergic mechanism in the early postpartum ewe Journal of Endocrinology 142 447-451

Snith RF, Gore SW, Phogat JB and Dobson H (1997) The psychological stress of transport stimulates both CRF and AVP secretion into hypohysial portal blood Journal of Endocrinology Supplement 152172

Taylor PL (1987) Munro Hormone Pulse-profile Analysis Elsevier, Amsterdam

Wheaton JE, Carlson KM, Windels HF and Johnston LJ (1993) CIDR - a new progesterone-releasing intravaginal device for induction of estrus and cycle control in sheep and goats Animal Reproduction Science 33 127-141 